\title{
Midge distribution patterns at multiple spatial scales in shallow Finnish lakes revealed through sedimentary records
}

\author{
Tomi P. Luoto, Liisa Nevalainen \& Veli-Pekka Salonen
}

Luoto, T. P., Nevalainen, L. \& Salonen, V.-P. 2012: Midge distribution patterns at multiple spatial scales in shallow Finnish lakes revealed through sedimentary records. - Entomol. Fennica 23: 83-94.

\begin{abstract}
This study was based on sedimentary midge (Diptera: Nematocera) assemblages from multilake datasets along environmental transects from Finland (regional), southern Finland (semiregional), and Helsinki district (local) and an intralake dataset from eastern Finland (site-specific). The aim was to examine scale-dependencies in midge distribution. The results imply that distribution and abundance of midge taxa are related to scale: on the regional scale the forcing factors are related to prevailing climate conditions, on semiregional scale they are related to water quality, on more local scales predation pressure is the key variable and on site-specific scales habitat characteristics determine the species assemblages. Although the number of study sites was not equal and not all environmental parameters were possible to measure from all spatial scales, it is apparent that caution is required in midge-based environmental assessments, because changes in faunal composition are driven by factors operating at different spatial scales.
\end{abstract}

T. P. Luoto, Department of Geosciences and Geography, University of Helsinki, P.O. Box 64, FI-00014 University of Helsinki, Finland \& Institute for Limnology, Austrian Academy of Sciences, Mondseestraße 9, A-5310 Mondsee, Austria; Email:tomi.luoto@helsinki.fi

L. Nevalainen, Institute for Limnology, Austrian Academy of Sciences, Mondseestraße 9, A-5310 Mondsee, Austria \& Environmental Protection and Research, City of Helsinki Environment Centre, P.O. Box 500, FI-00099 City of Helsinki, Finland

V.-P. Salonen, Department of Geosciences and Geography, University of Helsinki, P.O. Box 64, FI-00014 University of Helsinki, Finland

Received 21 April 2011, accepted 17 October 2011

\section{Introduction}

For the purposes of modern aquatic ecology, "palaeoecological" multilake datasets can be very informative, because they are able to provide large amounts of data on the modern distribution and abundance of taxa. Fossil assemblages in surface sediment samples, which provide integrated species data from a time period of several recent years, can sometimes be beneficial compared to traditional ecological monitoring. In the case of invertebrates that vary seasonally in their occurrence, such as larval midges (Insecta: Diptera: Nematocera) and water fleas (Crustacea: Cladocera) (Einarsson et al. 2002, Tátosová \& Stuchlík 2006, Nevalainen 2008, Nevalainen \& Sarmaja-Korjonen 2008), the use of ecological monitoring to establish modern distribution data 


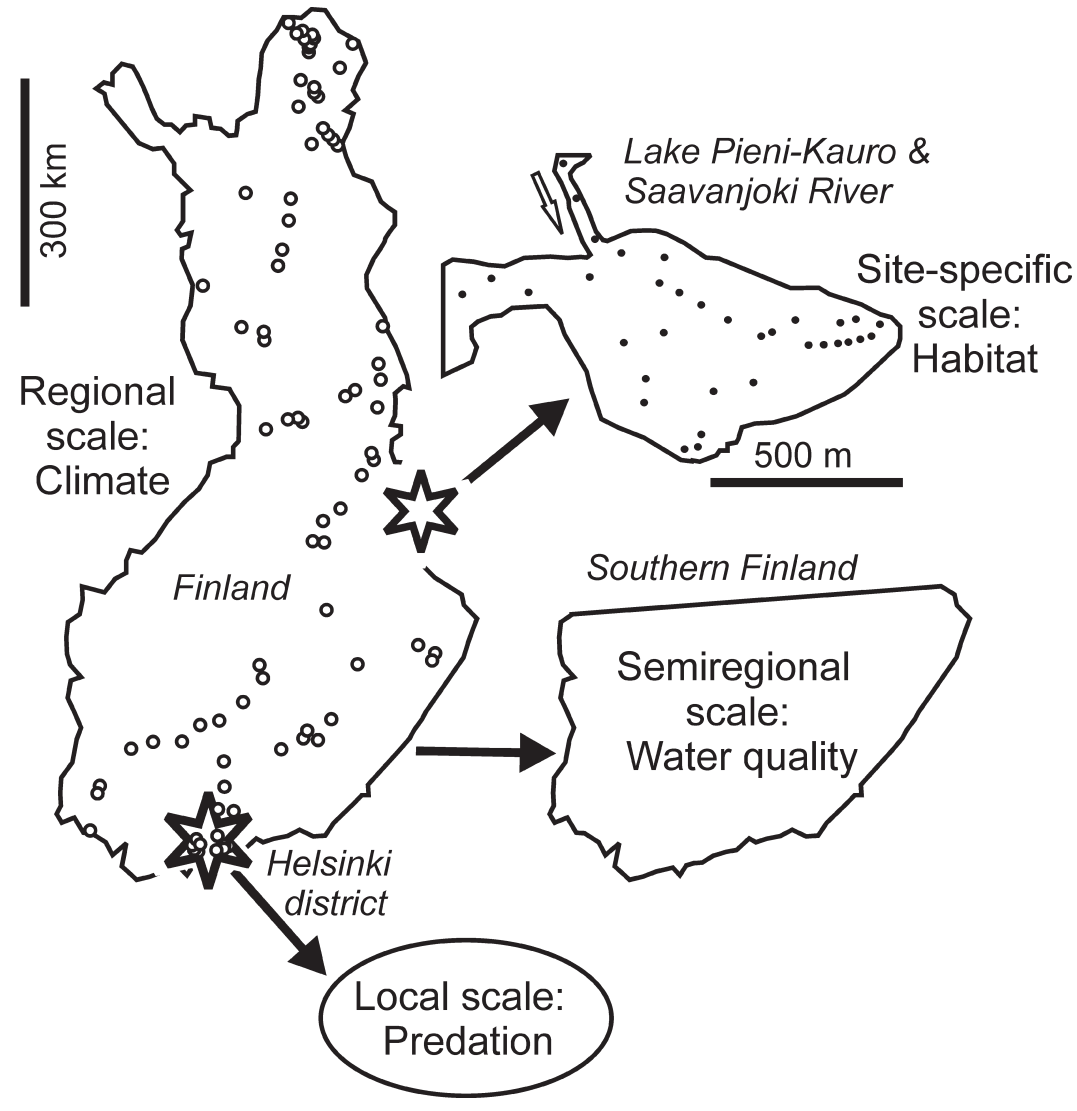

Fig. 1. The predominating forcing factors on midge distribution in Finland $\left(60-70^{\circ} \mathrm{N}\right)$ at multiple spatial scales. The lakes (regional dataset) are marked in open circles and sites (site-specific dataset) in black dots. The lakes in the semiregional and local datasets are all included in the regional dataset. in lakes would be very time- and resource-consuming and would also provide information on fewer taxa than the approach using sedimentary remains (Saros 2009, Nevalainen 2010). However, the fossil taxonomy of midges suffers from lower resolution compared to living larvae or pupal exuviae (Luoto \& Raunio 2011) and in addition, the traditional multilake (single-samples) approach does not distinguish which species inhabit particular habitats within a lake basin. Recent results from multisample studies within a single lake have shown that it is possible to distinguish habitat-specific information from surface sediment fossil data, as it appears that the sedimentary midge assemblages represent fauna that lived in close proximity to where their remains were deposited after moulting (instars) or death (Luoto 2010). There has also been recent major advancement in the identification of fossil midge remains and many of the taxa can now be identified to species-type level (Heiri et al. 2004, Brooks et al. 2007).
Macroinvertebrate communities respond to multiple environmental factors, many of which are scale-related (Vinson \& Hawkins 1998, Puntí et al. 2009). However, the ecological responses to scale are usually not linear (Krummel et al. 1987) and interpretation across scales have several problems, such as different mechanisms operating at different spatial scales (McIntyre 1997) and regional and local effects may be differing (Roth et al. 1996). Due to these problems, consideration of scale can affect estimation of community structure (Fuisz \& Moskát 1992) and, therefore, must not be ignored in ecology or palaeoecology. Although it is well known that multiple factors operating at various spatial and temporal scales shape species distribution (Levin 1992), less is known about how the determinants of the distributions (environmental forcing factors) vary across spatial scales, especially in the case of insects (Hortal et al. 2010). Importantly, changes in faunal composition driven by factors operating at different spatial scales can cause serious problems in 
Table 1. Mean values and range (in brackets) of the measured environmental variables in the regional, semiregional, local, and site-specific datasets and the lengths of DCA axis 1 and 2 based on the midge assemblages in each of the datasets. The single-point oxygen and $\mathrm{pH}$ measurements in the regional dataset were measured from only 51 lakes. Water colour and presence of fish (fish index, FI) were measured only from the local dataset and macrophytes (sample distance to littoral vegetation, DLV) and stream flow (lotic index, LI) only from the site-specific dataset.

\begin{tabular}{lllll}
\hline & Regional & Semiregional & Local & Site-specific \\
\hline$N$ & 82 (lakes) & 30 (lakes) & 9 (lakes) & $34($ sites $)$ \\
Sampling depth $(\mathrm{m})$ & $3.3(0.5-9.0)$ & $3.2(1.0-9.0)$ & $3.7(1.5-5.9)$ & $3.1(0.5-7.3)$ \\
Mean air T $\left({ }^{\circ} \mathrm{C}\right)$ & $14.9(11.3-17.1)$ & $16.5(15.9-17.1)$ & $16.6(16.4-17.1)$ & 15.3 \\
Elevation $(\mathrm{m})$ & $82.9(11.3-404.0)$ & $84.1(11.3-134.1)$ & $66.0(14.6-97.3)$ & 188.4 \\
Surface area $\left(\mathrm{km}^{2}\right)$ & $0.3(0.003-6.94)$ & $0.24(0.01-6.00)$ & $0.04(0.01-0.14)$ & 0.3 \\
Oxygen $\left(\mathrm{mg} \mathrm{I}^{-1}\right)$ & $5.6(0.5-11.8)$ & $5.0(0.5-11.8)$ & $8.9(5.6-11.8)$ & 10.9 \\
pH & $6.2(3.8-9.3)$ & $6.3(4.4-9.3)$ & $5.5(4.6-7.3)$ & 6.8 \\
Conductivity $\left(\mu \mathrm{cm}^{-1}\right)$ & $38.3(8-312)$ & $77(8-312)$ & $37(16-128)$ & 12 \\
Water colour $\left(\mathrm{Pt} \mathrm{mg} \mathrm{^{-1 }}\right)$ & No data & No data & $55(25-125)$ & No data \\
Presence of fish $(\mathrm{FI})$ & No data & No data & $0 / 1$ & No data \\
Macrophytes $(\mathrm{DLV} \mathrm{m})$ & No data & No data & No data & $185(0-270)$ \\
Stream flow $(\mathrm{LI})$ & No data & No data & No data & $0 / 1$ \\
Length of DCA axis 1 & 2.9 & 2.0 & 1.7 & 2.3 \\
Length of DCA axis 2 & 3.2 & 1.9 & 1.2 & 3.2 \\
\hline
\end{tabular}

midge-based environmental assessments, for example in lake management at the local/site-specific scale (reference conditions) or in climate change assessments at the global/regional scale (temperature dynamics). In addition, understanding scale-dependencies can be useful in conservation planning of insects (Cabeza et al. 2010).

In this study, we examine distribution patterns of fossil midges in shallow lakes in Finland. Midge-based datasets from the same region, but at different spatial scales, i.e. regional (Luoto 2009a), semiregional (Luoto \& Salonen 2010), local (Nevalainen \& Luoto 2010), and site-specific (Luoto 2010) datasets, are compared for their most important environmental forcing factors on midge taxa distribution and abundance. The datasets represent species-environment relationships at two grain sizes: the lake (regional, semiregional, and local datasets) and site (sitespecific dataset) levels. The hypothesis here is that different environmental factors have a dominant role at particular spatial scales.

\section{Study sites}

The study area is located in Finland, ranging from $60^{\circ} 13^{\prime}$ to $69^{\circ} 53^{\prime} \mathrm{N}$ and $22^{\circ} 00^{\prime}$ to $30^{\circ} 13^{\prime} \mathrm{E}$ (Fig.
1). The study sites span a $1,080 \mathrm{~km}$ latitudinal transect, from boreal coniferous forests in the south to tundra vegetation in the north. The examined 83 lakes are small and shallow (Table 1). The altitude of the lakes varies from 11 to $404 \mathrm{~m}$ above sea level (a.s.1.) and the mean July air temperature $\left(T_{\text {Jul }}\right)$ ranges from 11.3 to $17.1{ }^{\circ} \mathrm{C}$ (Table 1$)$. The mean annual precipitation varies within the area from 400 to $660 \mathrm{~mm}$ (Hyvärinen 1986). The surface sediment dataset representing the regional scale was collected from 82 of these sites. The dataset representing the semiregional scale was collected from 30 lakes in southern Finland $\left(60^{\circ} 13^{\prime}-63^{\circ} 05^{\prime} \mathrm{N}, 22^{\circ} 00^{\prime}-30^{\circ} 13^{\prime} \mathrm{E}\right)$ and the scaling is based on geographical distribution of the lakes. These lakes constitute from the southern lakes in the regional dataset. The vegetation in the catchments of the 30 lakes in this dataset consists of boreal coniferous forests. Some of the lakes are located in urban areas. In general, the study area at the semiregional scale is more influenced by human activity than that examined at the regional scale, although many of the sites have remained close to their pristine state. The limnological parameters: $\mathrm{pH}$, conductivity and dissolved oxygen (DO) in the regional and semiregional datasets were highly variable. More detailed site descriptions and environmental data 
are given in the original publications (Luoto 2009a, Luoto \& Salonen 2010).

The nine study lakes representing the local scale are distributed in close proximity to each other in southern Finland, near the Helsinki district (Fig. 1). The catchments consist of boreal coniferous forests and the lakes vary from oligo- to eutrophy. They are all basins without major inlets or outlets. Six of the lakes are currently inhabited by fish (Perca fluviatilis) and three lakes are currently without fish populations. These lakes also occur in the regional and semiregional datasets. More detailed descriptions of the sites and environmental data in the local dataset are given in a previous publication (Nevalainen \& Luoto 2010).

Samples of the site-specific dataset were derived from a dystrophic lake, Pieni-Kauro, situated in Kuhmo, eastern Finland (Fig. 1). The area is sparsely inhabited and the catchment is characterized by a drumlin landscape and wildernesslike coniferous forests. The northern shore of the lake is covered by wetlands and the Saavanjoki River enters the lake from the north, while the main outlet is on the western side. Lake PieniKauro is part of a larger lake complex connected by small rivers that originates in Russia and eventually drains into the Gulf of Bothnia in the Baltic Sea. A detailed site description, including aquatic vegetation patterns, is available in a previous publication (Luoto 2010). The samples were selected to represent different habitat types (substrate, vegetation, stream flow) and a water depth gradient (maximum depth $7.3 \mathrm{~m}$ ). In all, 34 samples were collected, of which three were riverine and 31 lacustrine. Lake Pieni-Kauro is not included in the other datasets.

\section{Material and methods}

The surface sediment samples of the regional $(N=82)$, semiregional $(N=30)$, and local $(N=9)$ datasets were obtained through the lake ice with a Limnos gravity corer (Kansanen et al. 1991) between February and April 2005. The surface sediment sampling of Lake Pieni-Kauro $(N=31)$ and its inlet, the Saavanjoki River $(N=3)$, (site-specific dataset) was performed in October 2008 from a boat, also using the Limnos corer. The sur- face sediment samples (topmost $0-1 \mathrm{~cm}$ ) used in this study represent the recent years of sedimentation. The fossil faunal assemblages in these samples can be considered as analogues of modern relative abundances (Frey 1960, Bunbury \& Gajewski 2008, Nykänen et al. 2009).

Limnological measurements were performed as single measurements taken in situ during the collection of the sediment samples with an Orion Model $1230 \mathrm{pH} / \mathrm{mV} / \mathrm{ORP} /$ conductivity/dissolved oxygen/salinity/temperature meter (Thermo Fisher Scientific, Waltham, MA, USA) before sediment sampling to avoid the resulting disturbance of the water column. The oxygen concentration was recorded ca. $0.5 \mathrm{~m}$ from the bottom at the sampling site and conductivity and $\mathrm{pH}$ from the epilimnion. The colour of water represents the platinum concentration in a platinum cobalt chloride solution that has the same colour as the sample. The depth was measured at the sampling point and is in fact the water depth at the sampling site, which does not mean the same as the maximum lake depth. The multilake dataset samples were taken from the sublittoral areas rather than from the deepest point to better include the littoral taxa. The modern mean air $T_{\text {Jul }}$ was estimated for each lake using a geographical information system (GIS)-based method. The temperature data were provided by the Finnish Meteorological Institute and were based on the 1971-2000 climate normals, which take into account all Finnish meteorological data. The temperature data were interpolated from the data of the meteorological stations to a $10 \times 10 \mathrm{~km}$ grid, taking into account factors such as elevation and lake coverage. The fish status of the lakes in the local dataset was determined by test fishing, diving, and available literature (Nyberg et al. 2010). The distance from the littoral vegetation (DLV) was measured and determined by examining aerial photographs and field observations and stream flow was determined simply by dividing the samples following their lotic or lentic distribution. For more details and other measured environmental parameters, consult the previous publications (Luoto 2009a, 2010, Luoto \& Helama 2010, Luoto \& Salonen 2010, Nevalainen \& Luoto 2010, Kultti et al. 2011).

The sediment samples were prepared applying standard methods for fossil midge analysis 
described in Hofmann (1986), Walker (2001), and Brooks et al. (2007). The sediments were sieved through a $100 \mu \mathrm{m}$ sieve and the midge remains extracted from the residues using a Bogorov counting chamber (Gannon 1971) or a Petri dish under a stereomicroscope (25-40 times magnification). The fossil remains were permanently mounted in Euparal ${ }^{\circledR}$ or Canada balsam (Rhenohistol ${ }^{\circledR}$ ) on microscope slides and identified to the highest taxonomic resolution possible under a light microscope at 400-times magnification. A minimum of 100 midge individuals were identified from each sample, which exceeds the recommended minimum count size of 40-50 head capsules for fossil chironomid analysis (Larocque 2001, Quinlan \& Smol 2001). The identification was mainly based on the guides of Wiederholm (1983) and Brooks et al. (2007). Heiri et al. (2004) was used to identify the Tanytarsini and Rieradevall and Brooks (2001) the Tanypodinae head capsules. The identification of Cricotopus pulchripes-type was based on the description of Nyman et al. (2005). The phantom midges (Chaoboridae), biting midges (Ceratopogonidae), and black flies (Simuliidae) were identified according to descriptions of Finnish specimens by Luoto and Nevalainen (2009), Luoto (2009b), and Luoto (2010). The black fungus gnats (Sciaridae) were identified according to Heiri and Lotter (2007).

All statistical re-analyses of the previously available data were performed using relative taxa abundances and square-root transformation of assemblage data to stabilize the variances of individual taxa expressed as percentages. Detrended correspondence analysis (DCA) was applied to choose between linear- or unimodal-based methods in further numerical analyses by estimating the lengths of compositional gradients (DCA axes 1 and 2). The DCAs were run with detrending by segments and down weighting of rare species. DCA is an indirect ordination method that summarizes the variation in species assemblages along latent gradients (ter Braak \& Šmilauer 2002). Canonical correspondence analysis (CCA) and redundancy analysis (RDA) were used to explore the relationships between midge assemblages and environmental variables. CCA is a unimodal ordination technique used with long gradient lengths and RDA is a linear ordination technique used with shorter gradient lengths. Both analyses can be used to identify environmental variables that are strongly related to the species assemblages (ter Braak \& Šmilauer 2002). The CCAs and RDAs were run with only one environmental variable (without any transformations) at a time and by using statistically significant co-variables. The statistical significance of each variable was tested with a Monte Carlo permutation test (999 unrestricted permutations), and variables were considered significant if the permutation test value $(P)$ was $\leq 0.01$. In the intralake dataset, habitat (stream flow) and the presence of Nuphar lutea L. Sm., Equisetum fluviatile L. and Phragmites australis (Cav) Trin. ex Steud. stands were entered as nominal variables, using binary codes (value 0 when absent and 1 when present). Habitat was entered as a "dummy" variable ( $0=$ lentic, $1=$ lotic $)$, because discharge can vary greatly among or within seasons and following a precipitation event (Gandoin et al. 2006). The stream flow analysis used all the 34 samples, but for other variables in the intralake dataset only the 29 lentic samples were used. The DCAs, CCAs and RDAs were performed using the program CANOCO, version 4.52 (ter Braak \& Šmilauer 2002).

Invertebrate-based cluster analysis (two-way indicator species analysis, TWINSPAN) was used as a divisive technique to group the lakes from the datasets and to identify indicator taxa for the environmental variables studied. TWINSPAN can be considered suitable for the present datasets, which consist of noisy data, many zero values, and high number of taxa (Gauch \& Wittaker 1981). TWINSPAN was performed using the program WinTWINS, version 2.3 (Centre for Ecology and Hydrology \& University of South Bohemia, Huntingdon \& České Budejovicě) (Hill \& Šmilauer 2005). Spatial analyses were performed using Mantel non-parametric tests on the midge assemblages to determine if spatial autocorrelation existed in the intralake dataset, which may be considered as a strongly spatially structured environment. A Bray-Curtis distance was used for the biological distance matrix and geographical distance between the sites for the spatial distance matrix $(1,000$ randomisations), following the example of Quinlan et al. (2003). The geographical distances between the 
Table 2. Summary of the statistically significant variables $(P \leq 0.01)$ affecting midge assemblages at different geographical scales in Finland. The number of observation sites $(N)$, results of the significance test $(P)$, species-environment correlations, and the proportion of variance explained. Species-environment correlation is the correlation between the site scores that are weighted averages of the species scores and the site scores and the site scores that are a linear combination of the environmental variables (Jongman et al. 1995). The regional, semiregional, and site-specific datasets were analyzed using the canonical correspondence analysis (CCA) and the local dataset using redundancy analysis (RDA). The values in brackets indicate results obtained by using statistically significant co-variables. In addition to the statistical tests, the gradient of the particular environmental variable in the dataset is shown.

\begin{tabular}{|c|c|c|c|c|c|c|}
\hline Scale & Variable & $N$ & $P$ & Correlation & $\begin{array}{l}\% \text { variance } \\
\text { explained }\end{array}$ & Gradient \\
\hline \multirow[t]{2}{*}{ Regional } & Mean air $\mathrm{T}_{\mathrm{Ju}}$ & 82 & $0.002(0.001)$ & $0.898(0.905)$ & $6.2(6.4)$ & $11.3-17.1^{\circ} \mathrm{C}$ \\
\hline & Water depth & 82 & $0.002(0.009)$ & $0.750(0.721)$ & $2.4(2.2)$ & $0.5-9.0 \mathrm{~m}$ \\
\hline \multirow[t]{3}{*}{ Semiregional } & DO & 30 & $0.002(0.005)$ & $0.923(0.881)$ & $9.1(6.2)$ & $0.5-11.8 \mathrm{mg} \mathrm{l}^{-1}$ \\
\hline & Conductivity & 30 & $0.002(0.040)$ & $0.876(0.868)$ & $7.5(5.2)$ & $8-312 \mu \mathrm{S} \mathrm{cm}{ }^{-1}$ \\
\hline & Mean air T & 30 & $0.002(0.003)$ & $0.817(0.815)$ & $6.7(6.9)$ & $15.9-17.1^{\circ} \mathrm{C}$ \\
\hline \multirow[t]{2}{*}{ Local } & Fish & 9 & $0.001(0.013)$ & $0.969(0.987)$ & $37.0(28)$ & $0 / 1 \mathrm{Fl}^{*}$ \\
\hline & Water colour & 9 & $0.004(0.115)$ & $0.900(0.978)$ & $29.2(21)$ & $25-125 \mathrm{Pt} \mathrm{mg} \mathrm{I}^{-1}$ \\
\hline \multirow[t]{3}{*}{ Site-specific } & Stream flow & 34 & $0.001(0.001)$ & $0.939(0.913)$ & $8.8(7.8)$ & $0 / 1 \mathrm{LI}^{* *}$ \\
\hline & Water depth & 29 & $0.001(0.001)$ & $0.924(0.920)$ & $8.6(7.2)$ & $0.5-7.3 \mathrm{~m}$ \\
\hline & Macrophytes & 29 & $0.001(0.082)$ & $0.938(0.900)$ & $7.9(4.6)$ & $0-270 m\left(D L V^{* * *}\right)$ \\
\hline
\end{tabular}

${ }^{*} \mathrm{FI}=$ fish index,${ }^{* *} \mathrm{LI}=$ lotic index,${ }^{* * *} \mathrm{DLV}=$ sampling distance to littoral vegetation

sampling points used coordinates, which were derived using a map tool because coordinates were not measured during the sediment sampling. Mantel test was performed using the program PAST (Hammer et al. 2001).

\section{Results and discussion}

The observed patterns of community structure can be affected by the scale of observation (Wiens 1989, Levin 1992) or by the fact that some biological phenomena are independent of scale (Aronson 1994). The ecological problems related to scale become more acute when studying temporal changes in community structure (Roemmich \& McGowan 1995) and their possible relationship with anthropogenic effects (Smith \& Buddemeier 1992). The temporal and spatial scales of observation are extremely important when interpreting changes in community structure (Edmunds \& Bruno 1996).

The results from the dataset across Finland (regional) suggested that the mean air $T_{\text {Jul }}$ is an important factor affecting chironomid distribution and abundance, together with sampling depth, whereas in the warm southern regions other factors also became significant (Table 2, Figs. 1, 2). The distribution of midge taxa in the regional dataset corresponded with general faunal observations made in Finland (Nyman et al. 2005, Paasivirta 2009, Raunio et al. 2010). Of the individual taxa, Psectrocladius (Monopsectrocladius) calcaratus-type, Micropsectra insignilobus-type, and Tanytarsus lugens-type preferred low temperature in the present dataset, while taxa such as Chironomus plumosus-type were more common in warm southern lakes (Fig. 2a). The temperature preferences were also evident in the TWINSPAN grouping of samples, which identified indicator taxa representative for different parts of the climatic gradient in the regional dataset (Fig. 3a). Apparently, many of the taxa succeeding in particular limnological conditions, such as an elevated trophic status, may also favour warm lakes (Fig. 3). It has been shown that in northern and alpine areas, nutrient conditions are related to summer temperatures, with cool lakes often having lower nutrient concentrations, while lowland areas at lower latitudes and altitudes are more often subject to anthropogenic nutrient enrichment (Brodersen \& Anderson 2002, Heiri \& Lotter 2005). This is also probably one of the reasons for the variation found in the faunal 


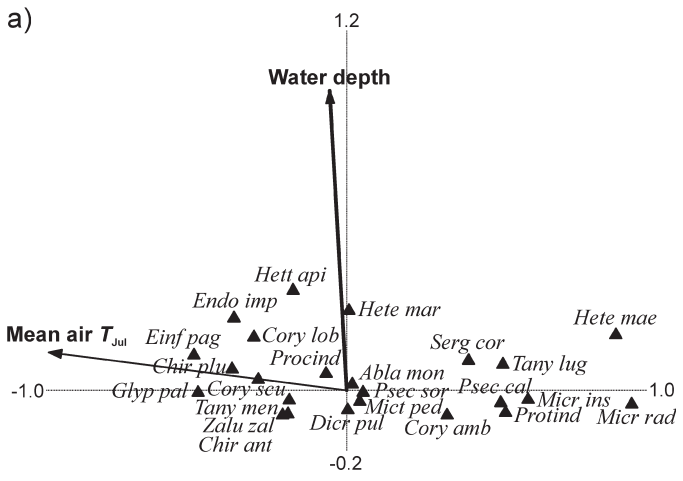

b)

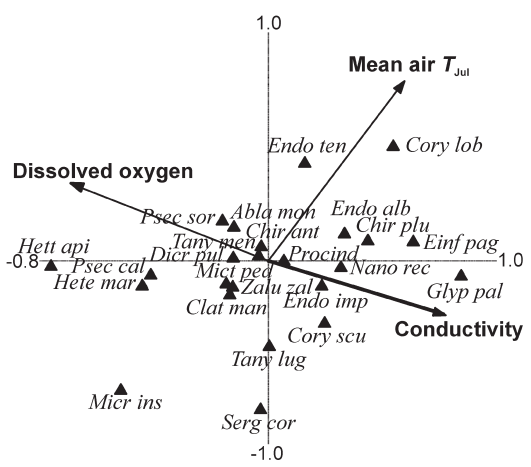

Fig. 2. Ordination plots of species (see Schnell et al. (1999) for standardized codes for taxon names) and the significant environmental variables using canonical correspondence analysis. - a. Regional dataset. b. Semiregional dataset.

assemblages in the present study, as the warm southern parts of Finland are extensively utilized by humans, whereas the environment in the cold northern Finland is more close to its natural state. Unfortunately, the remote northern sites in the present study could not be examined for their water quality in as close detail as the southern lakes due to broken measuring equipment.

In the dataset restricted to southern Finland (semiregional) with a temperature gradient of only $1.2{ }^{\circ} \mathrm{C}$, parameters closely related to water quality, including dissolved oxygen and conductivity, were the most important environmental factors associated with midge distribution and abundance (Table 2, Fig. 2b). Surprisingly, summer air temperature was still a statistically significant correlate even with the very narrow temperature gradient. Temperature, metabolism, and respiratory requirements are directly linked to each other, and respiration physiology is thus among the indirect causal responses and mechanisms making midges useful as indicators of climate (Brodersen et al. 2004, 2008). The oxygen conditions can change under stable temperature, but climate hardly ever changes without affecting the oxygen status (Brodersen \& Anderson 2002). Under significant temperature changes, oxygen, productivity, and climate in combination are probably the forcing factors determining midge distribution. It has remained unclear whether chironomids respond to temperature directly through physiological temperature tolerances or indirectly through changes in the lake habitat and other intralake processes (Anderson et al. 2008, Brodersen et al. 2008: Fig. 4). Nevertheless, previous studies confirm the present results that limnological factors can have an overwhelming influence in warmer climatic conditions or within short climatic gradients (Brodersen \& Lindegaard 1999, Brooks et al. 2001). However, of the limnological factors that were measured, $\mathrm{pH}$ was found not to have a significant influence on midge assemblages in the present regional and semiregional datasets (Luoto 2009a, Luoto \& Salonen 2010). This is in contrast with the results of Nyman et al. (2005), who showed that $\mathrm{pH}$ was an important explanatory variable in their semiregional dataset from north-western Finnish Lapland. It should also be noted that we found no significant correlation between air temperature and measured water quality parameters in the semiregional dataset.

The present results indicate that climate may determine the midge assemblages at the regional scale, whereas water quality may become more important at the semiregional scale (Table 2, Fig. 1). Interestingly, these parameters are closely related as climate strongly regulates lake productivity (Cohen 2003). Progressive eutrophication unavoidably leads to changes in biota and biodiversity, blue-green algal blooms, hypolimnetic oxygen depletions, and fish kills. These changes obviously affect also the midge distribution through various feedback mechanisms at many levels. The potentially confounding phenomenon of midge trophic and climate optima being correlated may be alleviated when a dataset is properly interpreted in a scale-appropriate context.

The TWINSPAN classification of the nine study lakes representing the local scale showed 


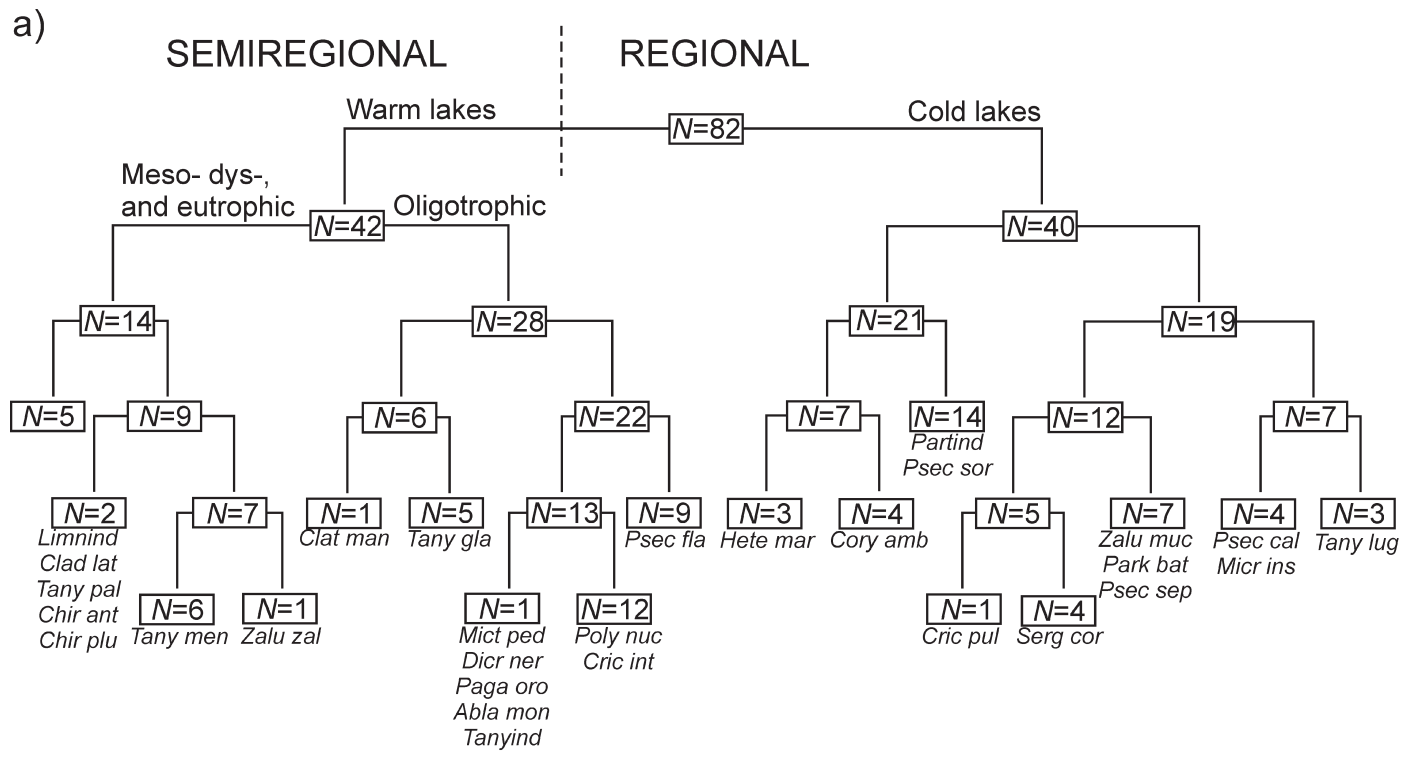

b)

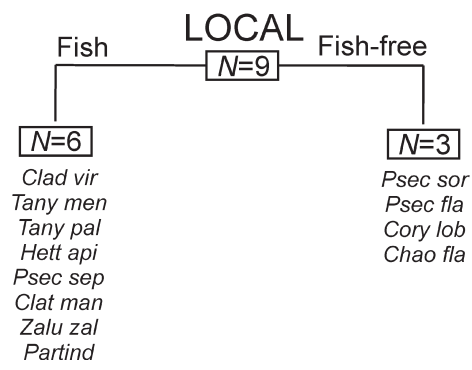

c) SITE-

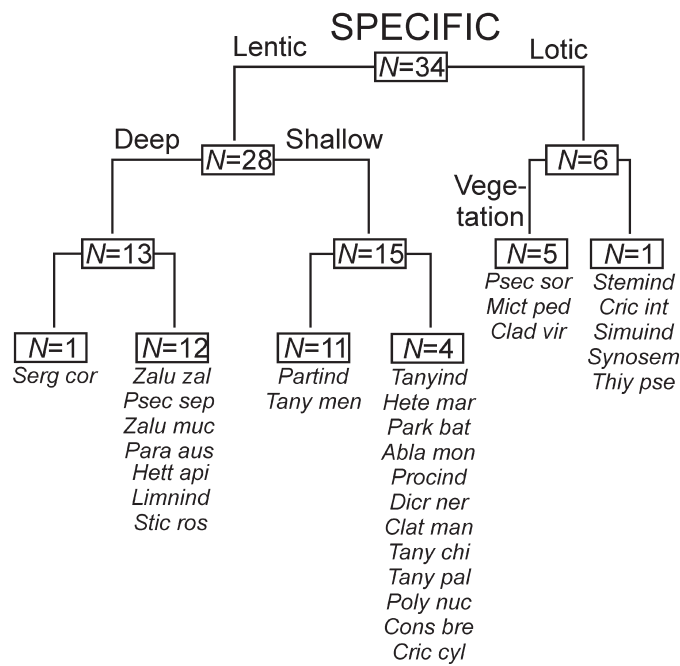

Fig. 3. TWINSPAN grouping of lakes and the assigned indicator taxa (see Schnell et al. (1999) for standardized codes for taxa names) based on the midge assemblages in Finland. - a. Regional and semiregional datasets. b. Local dataset. - c. Site-specific dataset.

that the three lakes with no fish stocks were grouped together (Fig. 3b), suggesting that the faunal assemblages in fish-free lakes differ from those with fish, namely Perca fluviatilis, which is known to prey on chironomids (Diehl 1995). Most of the taxa were found in lakes with fish, but taxa such as Psectrocladius (P.) sordidellus-type, Psectrocladius (A.) flavus-type, Corynoneura lobata-type, and Chaoborus flavicans-type were completely restricted to fish-free sites. Chaoborus flavicans is known to co-occur with fish only in deep basins that provide refugia in the hypolimnion, in clay-turbid basins that prevent visual predation by fish, and in humic brown-watered basins that have reduced fish predation potential due to their light-, oxygen-, and temperature profiles (Liljendahl-Nurminen 2006). Interestingly, in addition to fish stock, water colour 
was the only environmental factor that was found statistically significant in the present study (Table 2) and the fish-free lakes in the dataset were those with dystrophic brown water (Nevalainen \& Luoto 2010). However, when the CCA was run for water colour with the fish data as a co-variable, the influence of colour became statistically insignificant for midges. Because the number of samples in the local dataset was very low, the present results remain inconclusive and must be treated with caution.

A Mantel test on the intralake dataset indicated that the midge assemblages exhibited statistically significant spatial autocorrelation $(P=$ $0.04)$, but this relationship was very weak $(r=$ $0.07)$. The results also showed that hydrological variables of stream flow and water depth were important factors controlling midge distribution when the study was scaled to a single lake and the aquatic vegetation patterns also contributed as a significant explanatory variable when the marginal effects were examined (Table 2). The taxa richness in the surface sediments of Lake PieniKauro and the Saavanjoki River (site-specific dataset) was very high, since over 100 midge taxa were encountered (Luoto 2010). This was most likely due to the great diversity of habitats available for midges, including lentic and lotic environments with different exposures, substrata, and vegetation types. Furthermore, the midge assemblages showed significant habitat-related heterogeneity between the samples and the taxa were divided into clear indicator groups based on their habitat preferences in the intralake dataset (Fig. $3 c)$. The profundal zone in Lake Pieni-Kauro was dominated by the cold-indicating Heterotrissocladius maeaeri-type, while it was absent from other parts of the lake (Luoto 2010). Many other typical cold water taxa, such as Sergentia coracina-type, were also restricted to the profundal zone. The littoral areas of Lake Pieni-Kauro were characterized by taxa such as Cladotanytarsus mancus-type and Tanytarsus mendax-type, while the riverine samples were dominated by Thienemannimyia pseudocarnea-type and Simulium, fitting well with previous data on their ecology (Wiederholm 1983, Currie \& Walker 1992, Gandoin et al. 2006, Brooks et al. 2007). Psectrocladius (P.) sordidellus-type and Cladopelma viridulum were strongly associated with Phrag- mites australis stands (Luoto 2010), which is in agreement with previous records of these taxa in Finland (Tolonen et al. 2001).

The fact that some lakes in this study are in urban areas and the semi-regional scale has more lakes affected by human activities than the regional scale does cause some bias due to uneven distribution of human impact. Furthermore, the environmental gradients are not the same between scales and not all parameters could be tested between the datasets (e.g. climate vs. inlake processes), hence making the comparisons between them less successful. Although benthic communities can be sampled at almost any scale, not all environmental variables can be measured reasonably from all the scales. Nevertheless, the present implication that different causative processes are important at different scales is in agreement with the conclusions made by Walker et al. (1992). The ultimate environmental forcing factors vary among different taxa, but it is also a matter of spatial and environmental scaling; at the regional scale the ultimate forcing factor is probably the prevailing summer temperature, at the semiregional scale water quality becomes more important, at the local scale fish predation can control the midges, and at the site-specific scale habitat characteristics determine the species composition. However, many of these forcing factors are interconnected and the influence of a particular parameter is often indirect and mediated through other environmental factors. It is also intriguing that some of the parameters may be important at several scales; summer air temperature at the regional and semiregional scales and water depth at the regional and site-specific scales. In the future, it would be important to aim to examine midge distribution across spatial scales with all the parameters examined from all the scales.

One of the most important implications in this study is that locally the predation pressure caused by fish may have overwhelming influence on the midge community composition. Therefore, an introduction or disappearance of fish, or just a change in the size of fish stock can potentially cause a very serious bias in any midge-based environmental assessment. In addition to the influence of food web changes, intralake processes, including changes in hydrology (water depth, stream flow) and in habitat availability (e.g. 
macrophytes) may cause problems when examining the determinants of a community and its dynamics. At the different spatial scales, community structure is driven by several interconnected factors such as local history, different rates of change of community structure and the patchy effects of stochastic events (e.g. disturbances and recruitment). However, in accordance with previous studies (e.g. Sorebón \& Nakamura 2009), abiotic conditions are fundamental at large scales and bionomic effects at smaller scales that makes a theoretic background to link the different descriptions of species distribution across scales and the factors influencing them (Hortal et al. 2010). The scenopoetic factors, which become neglible at site scales, are responsible of number of processes influencing species distributions, including physiological constraints, responses to climate and habitat gradients, active habitat selection, and range shifts in response to change in climate or habitat (Hortal et al. 2010). Furthermore, previous studies have confirmed that climate can regulate the ranges of species at large scales, while variables related to habitat operate at local and site-specific scales (Pearson \& Dawson 2003, Thuiller et al. 2004). To understand species distributions and the effects of forcing factors, it is necessary to consider the effect of scale (Hui et al. 2010). It is also important to understand that no single scale can be considered "correct" for system analysis (Levin 1992) and extreme caution should be used when scaling the results to scales that were not sampled.

Acknowledgements. This research was funded by the EPHIPPIUM project (Academy of Finland, grant no. 1107062) and the INFER (INtralake Fossil InvERtebrate assemblages) project. Research grants from the Finnish Entomological Society, Kone Foundation, and Academy of Finland (grant no. 250343) for T. P. Luoto are also well appreciated. We thank the two anonymous reviewers for their detailed comments and constructive criticism that greatly improved the quality of the manuscript.

\section{References}

Anderson, N. J., Brodersen, K. P., Ryves, D. B., McGowan, S., Jeppesen, E. \& Leng, M. J. 2008: Climate versus in-lake processes as controls on the development of community structure in a low-arctic lake (SouthWest Greenland). — Ecosystems 11: 307-324.
Aronson, R. B. 1994: Scale-independent biological processes in marine environment. - Oceanography and Marine Biology: An Annual Review 32: 435-460.

Brodersen, K. \& Anderson, N. J. 2002: Distribution of chironomids (Diptera) in low arctic West Greenland lakes: trophic conditions, temperature and environmental reconstruction. - Freshwater Biology 47: 11371157.

Brodersen, K. P. \& Lindegaard, C. 1999: Classification, assessment and trophic reconstruction of Danish lakes using chironomids. - Freshwater Biology 42: 143157.

Brodersen, K. P., Pedersen, O., Lindegaard, C. \& Hamburger, K. 2004: Chironomids (Diptera) and oxy-regulatory capacity: An experimental approach to paleolimnological interpretation. - Limnology and Oceanography 49: 1549-1559.

Brodersen, K. P., Pedersen, O., Walker, I. R. \& Jensen, M. R. 2008: Respiration of midges (Diptera: Chironomidae) in British Columbian lakes: oxy-regulation, temperature and their role as palaeo-indicators. - Freshwater Biology 53: 593-602.

Brooks, S. J., Bennion, H. \& Birks, H. J. B. 2001: Tracing lake trophic history with a chironomid-total phosphorus inference model. — Freshwater Biology 46: 513 533.

Brooks, S. J., Langdon, P. G. \& Heiri, O. 2007: The identification and use of Palaeoarctic Chironomidae larvae in palaeoecology. QRA Technical Guide No. 10. Quaternary Research Association, London. 276 pp.

Bunbury, J. \& Gajewski, K. 2008: Does a one point sample adequately characterize the lake environment for paleoenvironmental calibration studies? - Journal of Paleolimnology 39: 511-531.

Cabeza, M., Arponen, A., Jäättelä, L., Kujala, H., van Teeffelen, A. \& Hanski, I. 2010: Conservation planning with insects at three different spatial scales. Ecography 33: 64-72.

Carpenter, S. R. 2003: Regime shifts in lake ecosystems: pattern and variation. Volume 15: Excellence in Ecology Series. - Ecology Institute, Oldendorf/Luhe. 199 pp.

Cohen, S. C. 2003: Paleolimnology. The history and evolution of lake systems. - Oxford University Press, Oxford. $500 \mathrm{pp}$.

Currie, D. C. \& Walker, I. R. 1992: Recognition and palaeohydrologic significance of fossil black fly larvae, with a key to the Nearctic genera (Diptera: Simuliidae). - Journal of Paleolimnology 7: 37-54.

Diehl, S. 1995: Direct and indirect effects of omnivory in a littoral lake community. — Ecology 76: 1727-1740.

Edmunds, P. J. \& Bruno, J. F. 1996: The importance of sampling scale in ecology: kilometer-wide variation in coral reef communities. - Marine Ecology Progress Series 143: 165-171.

Einarsson, Á., Gardarsson, A., Gíslason, G. M. \& Ives, A. R. 2002: Consumer-resource interactions and cyclic population dynamics of Tanytarsus gracilentus (Diptera: Chironomidae). - Journal of Animal Ecology 71: 832-845. 
Frey, D. G. 1960: The ecological significance of cladoceran remains in lake sediments. - Ecology 41: 684699.

Fuisz, T. \& Moskát, C. 1992: The importance of scale in studying beetle communities: hierarchical sampling or sampling the hierarchy? - Acta Zoologica Academiae Scientiarum Hungaricae 38: 183-197.

Gandoin, E., Maasri, A., Van Vliet-Lanoë, B. \& Franquet, E. 2006: Chironomid (Insecta: Diptera) assemblages from a gradient of lotic and lentic waterbodies in river floodplains of France: a methodological tool for paleoecological applications. - Journal of Paleolimnology 35: 149-166.

Gannon, J. E. 1971: Two counting cells for the enumeration of zooplankton micro-crustacea. - Transactions of the American Microscopical Society 90: 486-490.

Gauch, H. G. \& Whittaker, R. H. 1981: Hierarchical classification of community data. - Journal of Ecology 69: 537-557.

Hammer, Ø., Harper, D. A. T. \& Ryan, P. D. 2001: PAST: paleontological statistics software package for education and data analysis. — Palaeontologica Electronica 4: $9 \mathrm{pp}$.

Heiri, O. \& Lotter, A. F. 2005: Holocene and Lateglacial summer temperature reconstruction in the Swiss Alps based on fossil assemblages of aquatic organism: a review. - Boreas 34: 506-516.

Heiri, O. \& Lotter, A. F. 2007: Sciaridae in lake sediments: indicators of catchment and stream contribution to fossil insect assemblages. - Journal of Paleolimnology 38: 183-189.

Heiri, O., Ekrem, T. \& Willasen, E. 2004: Larval head capsules of European Micropsectra, Paratanytarsus and Tanytarsus (Diptera: Chironomidae: Tanytarsini) [www document]. URL http://stage.bio.uu.nl/palaeo/Chironomids/Tanytarsini/intro.htm. (Site visited on 14 July, 2011).

Hill, M. O. \& Šmilauer, P. 2005: TWINSPAN for Windows, Version 2.3. - Centre for Ecology and Hydrology \& University of South Bohemia, Huntington \& České Budejovicě.

Hofmann, W. 1986: Chironomid analysis. — In: Berglund, B. E. (ed.), Handbook of Holocene Palaeoecology and Palaeohydrology: 715-727. John Wiley \& Sons, New York.

Hortal, J., Roura-Pascual, N., Sanders, N. J. \& Rahbek, C. 2010: Understanding (insect) species distributions across spatial scales. - Ecography 33: 51-53.

Hui, C., Veldtman, R. \& McGeoch, M. A. 2010: Measures, perceptions and scaling patterns of aggregated species distributions. - Ecography 33: 95-102.

Hyvärinen, V. 1986: Vesitase. — In: Karlsson, K.-P. (ed.), Vedet. Suomen Kartasto 132: 12-13. Maanmittaushallitus ja Suomen Maantieteellinen Seura, Helsinki. [In Finnish.]

Jongman, R. H. G., ter Braak, C. J. F. \& van Tongeren, O. F. R. 1995: Data analysis in community and landscape ecology. - Cambridge University Press, Cambridge. $324 \mathrm{pp}$.

Kansanen, P., Jaakkola, T., Kulmala, S. \& Suutarinen, R.
1991: Sedimentation and distribution of gamma-emitting radionuclides in bottom sediments of southern Lake Päijänne, Finland, after the Chernobyl accident. Hydrobiologia 222: 121-140.

Krummel, J. R., Gardner, R. H., Sugihara, G., O’Neill, R. V. \& Coleman, P. R. 1987: Landscape patterns in a disturbed environment. - Oikos 48: 321-324.

Kultti, S., Nevalainen, L., Luoto, T. P. \& Sarmaja-Korjonen, K. 2011: Subfossil chydorid (Cladocera, Chydoridae) ephippia as paleoenvironmental proxies: evidence from boreal and subarctic lakes in Finland. Hydrobiologia DOI: 10.1007/s10750-011-0869-z.

Larocque, I. 2001: How many chironomid head capsules are enough? A statistical approach to determine sample size for palaeoclimatic reconstructions. - Palaeogeography, Palaeoclimatology, Palaeoecology 172: 133-142.

Levin, S. A. 1992: The problem of pattern and scale in ecology. - Ecology 73: 1943-1967.

Liljendahl-Nurminen, A. 2006: Invertebrate predation and trophic cascades in a pelagic food web - the multiple roles of Chaoborus flavicans (Meigen) in a clay-turbid lake. - PhD dissertation. Helsinki, University of Helsinki. 35 pp.

Luoto, T. P. 2009a: Subfossil Chironomidae (Insecta: Diptera) along a latitudinal gradient in Finland: development of a new temperature inference model. - Journal of Quaternary Science 24: 150-158.

Luoto, T. P. 2009b: An assessment of lentic ceratopogonids, ephemeropterans, trichopterans and oribatid mites as indicators of past environmental change in Finland. - Annales Zoologici Fennici 46: 259-270.

Luoto, T. P. 2010: Hydrological change in lakes inferred from midge assemblages through use of an intralake calibration set. - Ecological Monographs 80: 303329.

Luoto, T. P. \& Helama, S. 2010: Palaeoclimatological and palaeolimnological records from fossil midges and tree-rings: the role of the North Atlantic Oscillation in eastern Finland through the Medieval Climate Anomaly and Little Ice Age. - Quaternary Science Reviews 29: 2412-2424.

Luoto, T. P. \& Nevalainen, L. 2009: Larval chaoborid mandibles in surface sediments of small shallow lakes in Finland - implications for palaeolimnology. - Hydrobiologia 631: 185-195.

Luoto, T. P. \& Raunio, J. 2011: A comparison of chironomid-based total phosphorus training sets developed from contemporary pupal exuviae and sedimentary larval head capsules to infer lake trophic history. Fundamental and Applied Limnology 179: 93-102.

Luoto, T. P. \& Salonen, V.-P. 2010: Fossil midge larvae (Diptera: Chironomidae) as quantitative indicators of late-winter hypolimnetic oxygen in southern Finland: a calibration model, case studies and potentialities. Boreal Environment Research 15: 1-18.

McIntyre, N. E. 1997: Scale-dependent habitat selection by the darkling beetle Eleodes hispilabris (Coleoptera: Tenebrionidae). - The American Midland Naturalist Journal 138: 230-235. 
Nevalainen, L. 2008: Parthenogenesis and gamogenesis in seasonal succession of chydorids (Crustacea, Chydoridae) in three low-productive lakes as observed with activity traps. - Polish Journal of Ecology 56: 85-97.

Nevalainen, L. 2010: Evaluation of microcrustacean (Cladocera, Chydoridae) biodiversity based on sweep net and surface sediment samples. —Écoscience 17:356364.

Nevalainen, L. \& Luoto, T. P. 2010: Implications for the use of sedimentary invertebrate communities to infer past presence of fish. - Knowledge and Management of Aquatic Ecosystems 396: 1-13.

Nevalainen, L. \& Sarmaja-Korjonen, K. 2008: Timing of sexual reproduction in chydorid cladocerans (Anomopoda, Chydoridae) from nine lakes in southern Finland. - Estonian Journal of Ecology 57: 21-36.

Nyberg, K., Vuorenmaa, J., Tammi, J., Nummi, P., Väänänen, V.-M., Mannio, J. \& Rask, M. 2010: Re-establishment of perch in three lakes recovering from acidification: rapid growth associated with abundant food resources. - Boreal Environment Research 15: 480490.

Nykänen, M., Vakkilainen, K., Liukkonen, M. \& Kairesalo, T. 2009: Cladoceran remains in lake sediments: a comparison between plankton counts and sediment records. - Journal of Paleolimnology 42: 551-570.

Nyman, M., Korhola, A. \& Brooks, S. J. 2005: The distribution and diversity of Chironomidae (Insecta: Diptera) in western Finnish Lapland, with special emphasis on shallow lakes. - Global Ecology and Biogeography $14: 137-153$.

Paasivirta, L. 2009: Chironomidae (Diptera: Nematocera) in the biogeographical provinces of Finland. - [www document]. URL http://www.ymparisto.fi/download.asp .contentid $=82649 \&$ lan $=$ sv. (Site visited on 20 August, 2010).

Pearson, R. G. \& Dawson, T. P. 2003: Predicting the impacts of climate change on distribution of species: are bioclimatic envelope models useful? - Global Ecology and Biogeography 12: 361-371.

Puntí, T., Rieradevall, M. \& Prat, N. 2009: Environmental factors, spatial variation, and specific requirements of Chironomidae in Mediterranean reference streams. Journal of the North American Benthological Society 28: 247-265.

Quinlan, R. \& Smol, J. P. 2001: Setting minimum head capsule abundance and taxa deletion criteria in chironomid-based inference models. - Journal of Paleolimnology 26: 327-342.

Quinlan, R., Paterson, A. M., Hall, R. I., Dillon, P. J., Wilkinson, A. N., Cumming, B. F., Douglas, M. S. V. \& Smol, J. P. 2003: A landscape approach to examining spatial patterns of limnological variables and long-ter$\mathrm{m}$ environmental change in a southern Canadian lake district. — Freshwater Biology 48: 1676-1697.

Raunio, J., Paasivirta, L. \& Hämäläinen, H. 2010: Assessing lake trophic status using spring-emerging chironomid pupal exuviae. - Fundamental and Applied Limnology (Archiv für Hydrobiologie) 176: 61-73.

Rieradevall, M. \& Brooks, S. J. 2001: An identification guide to subfossil Tanypodinae larvae (Insecta: Diptera: Chironomidae) based on cephalic setation. - Journal of Paleolimnology 25: 81-99.

Roemmich, D. \& McGowan, J. 1995: Climatic warming and the decline of zooplankton in the Californian current. - Science 267: 1324-1326.

Roth, N. E., Allen, J. D. \& Erickson, D. L. 1996: Landscape influences on stream biotic integrity assessed at multiple spatial scales. - Landscape Ecology 11: 141-156.

Saros, J. E. 2009: Integrating neo- and paleolimnological approaches to refine interpretations of environmental change. - Journal of Paleolimnology 41: 243-252.

Schnell, Ø. A., Rieradevall, M., Granados, I. \& Hanssen, O. 1999: A chironomid taxa coding system for use in ecological and palaeoecological databases. - NIVA Report SNO 3710-97. 24 pp.

Smith, S. V. \& Buddemeier, R. W. 1992: Global change and coral reef ecosystems. - Annual Review of Ecology and Systematics 23: 89-118.

Sorebón, J. \& Nakamura, M. 2009: Niches and distributional areas: concepts, methods, and assumptions. Proceedings of the National Academy of Sciences 106: 19644-19650.

Tátosová, J. \& Stuchlík, E. 2006: Seasonal dynamics of chironomids in the profundal zone of a mountain lake (Ladové pleso, the Tatra Mountains, Slovakia). Biologia, Bratislava, 61/Suppl. 18: 203-212.

ter Braak, C. J. F. \& Šmilauer, P. 2002: CANOCO reference manual and CanoDraw for Windows User's guide: Software for community ordinations (Version 4.5). - Microcomputer Power, Ithaca. 500 pp.

Thuiller, W., Araújo, M. B. \& Lavorel, S. 2004: Do we need land-cover data to model species distribution in Europe? - Journal of Biogeography 31: 353-361.

Tolonen, K. T., Hämäläinen, H., Holopainen, I. J. \& Karjalainen, J. 2001: Influences of habitat type and environmental variables on littoral macroinvertebrate communities in a large lake system. - Archiv für Hydrobiologie 152: 39-67.

Vinson, M. R. \& Hawkins, C. P. 1998: Biodiversity of stream insects: variation at local, basin, and regional scales. - Annual Review of Entomology 43: 271-293.

Walker, I. R. 2001: Midges: Chironomidae and related Diptera. - In: Smol, J. P., Birks, H. J. B. \& Last, W. M. (eds.), Tracking environmental change using lake sediments. Volume 4: Zoological indicators: 43-66. Kluwer Academic Publishers, Dordrecht.

Walker, I. R., Engström, D. R. \& Birks, H. J. B. 1992: Aquatic invertebrates, climate, scale, and statistical hypothesis testing: a response to Hann, Warner and Warwick. - Canadian Journal of Fisheries and Aquatic Sciences 49: 1276-1280.

Wiederholm, T. 1983 (ed.): Chironomidae of the Holarctic region: keys and diagnoses. Part 1. Larvae. - Entomologica Scandinavica Supplement 19. Borgströms Tryckeri AB, Motala. 457 pp.

Wiens, J. A. 1989: Spatial scaling in ecology. — Functional Ecology 3: 385-397. 